\title{
The association of complex liver disorders with HBV genotypes
} prevalent in Pakistan

\author{
Saeeda Baig*1, Anwar Ali Siddiqui², Waqaruddin Ahmed ${ }^{3}$, Huma Qureshi ${ }^{4}$ \\ and Ambreen Arif ${ }^{5}$
}

\begin{abstract}
Address: ${ }^{1}$ Associate professor, Department of Biochemistry, Ziauddin Medical College, Ziauddin University, Karachi, Pakistan, ${ }^{2}$ Associate Dean, Department of Research and Department of Biological and Biomedical Sciences, Aga Khan University, Karachi, Pakistan, ${ }^{3}$ Incharge, Pakistan Medical Research Council, Jinnah Postgraduate Medical Center, Karachi, Pakistan, ${ }^{4}$ Executive Director Pakistan Medical Research Council, Islamabad, Pakistan and ${ }^{5}$ Research Officer, Pakistan Medical Research Council, Jinnah Postgraduate Medical Center, Karachi, Pakistan

Email: Saeeda Baig* - baigsaeeda@yahoo.com; Anwar Ali Siddiqui - anwar.siddiqui@aku.edu; Waqaruddin Ahmed - pmrcjpmc@hotmail.com; Huma Qureshi - pmrc@comsats.net.pk; Ambreen Arif - pmrcjpmc@ hotmail.com

* Corresponding author
\end{abstract}

Published: 27 November 2007

Virology Journal 2007, 4:128 doi:10.1186/1743-422X-4-128

This article is available from: http://www.virologyj.com/content/4/I//28

(C) 2007 Baig et al; licensee BioMed Central Ltd.

This is an Open Access article distributed under the terms of the Creative Commons Attribution License (http://creativecommons.org/licenses/by/2.0), which permits unrestricted use, distribution, and reproduction in any medium, provided the original work is properly cited.
Received: 12 October 2007

Accepted: 27 November 2007

\begin{abstract}
Background: Genotyping of HBV is generally used for determining the epidemiological relationship between various virus strains and origin of infection mostly in research studies. The utility of genotyping for clinical applications is only beginning to gain importance. Whether HBV genotyping will constitute part of the clinical evaluation of Hepatitis B patients depends largely on the availability of the relevance of the evidence based information. Since Pakistan has a HBV genotype distribution which has been considered less virulent as investigated by earlier studies from south East Asian countries, a study on correlation between HBV genotypes and risk of progression to further complex hepatic infection was much needed
\end{abstract}

Methods: A total of 295 patients with $\mathrm{HBsAg}$ positive were selected from the Pakistan Medical Research Council's (PMRC) out patient clinics. Two hundred and twenty six $(77 \%)$ were males, sixty nine (23\%) were females ( $M$ to $F$ ratio $3.3: 1$ ).

Results: Out of 295 patients, I56 (53.2\%) had Acute(CAH), 7I (24.2\%) were HBV Carriers, 54 (18.4\%) had Chronic liver disease (CLD) Hepatitis. 14 (4.7\%) were Cirrhosis and HCC patients. Genotype D was the most prevalent genotype in all categories of HBV patients, Acute (108), Chronic (39), and Carrier (53).

Cirrhosis/HCC (7) were HBV/D positive. Genotype A was the second most prevalent with 28 $(13 \%)$ in acute cases, $12(22.2 \%)$ in chronics, $14(19.7 \%)$ in carriers and 5 (4I.7) in Cirrhosis/HCC patients. Mixed genotype (A/D) was found in 20 (I2.8\%) of Acute patients, 3 (5.6\%) of Chronic and $4(5.6 \%)$ of carriers, none in case of severe liver conditions.

Conclusion: Mixed HBV genotypes A, D and A/D combination were present in all categories of patients except that no A/D combination was detected in severe conditions. Genotype $D$ was the dominant genotype. However, genotype $A$ was found to be more strongly associated with severe liver disease. Mixed genotype (A/D) did not significantly appear to influence the clinical outcome. 


\section{Background}

HBV is a classical virus that has amazed the researchers and clinicians around the world first with geographic relationship of its genotypes then secondly the association of its different genotypes with a wide spectrum of clinical manifestations. In the recent years, there has been an explosion of knowledge regarding clinical significance of HBV genotypes in terms of clinical outcomes and therapeutic response to antiviral therapy in patients with $\mathrm{HBV}$ related severe liver conditions [1]. Approximately 2 billion people in the world are infected by HBV [2], More than 350 million people are chronic carriers of the virus [3] Acute hepatitis of varying severity exists in 95\% of children and $2-10 \%$ of adult patients [4]. Overall, less than $1 \%$ of acute infections lead to fulminant hepatitis and death. Approximately $0-10 \%$ of infected adults become chronic carriers of HBV $[5,6]$. Chronic HBV infection is currently the most common cause of cirrhosis and hepatocellular carcinoma (HCC) in the world. Fifteen to $40 \%$ of chronically infected people may develop cirrhosis and HCC, the remaining individuals become asymptomatic carriers. In perinatal transmission, there is a strong chance for the child to become chronically infected compared to the infection acquired during adulthood,(about 10\% to $20 \%)[7,8]$.

Initially studies on the effect of genotypes on disease progression were reported from South-east Asian countries where HBV is hyperendemic. Since genotypes B and C are most prevalent in this region severity of liver dysfunction was found associated with these genotypes. Patients infected with genotype $\mathrm{C}$ were found having higher HBVDNA levels compared with those infected with genotype B [9-11], A, and D [12], in some studies but not in others $[13,14]$. Pakistan, according to WHO, falls in the low endemic area of HBV infection with prevalence of 3\% infected population. Studies from Pakistan focused more towards the HBV prevalence rate $[15,16]$, epidemiological issues [17], genotyping of most prevalent strain and its genetic variability regarding core region.[18] Since the most prevalent genotype is $\mathrm{D}$ [18] coexisting with less prevalent genotype A and A+D less than 20\% [19], it was required to investigate the virulence of these genotypes, especially regarding genotype $\mathrm{D}$ which has been found as less virulent and genotype of the asymptomatic carriers by earlier studies from south East Asian countries. This research study was conducted to assess the correlation between HBV genotype $\mathrm{D}, \mathrm{A}$ and $\mathrm{A}+\mathrm{D}$ and risk of progression to further complex hepatic infections such as chronic, acute, cirrhosis and HCC.

\section{Results}

Two hundred and ninety five HBsAg positive registered patients were selected from the PMRC OPD. Two hundred and twenty six (76.6\%) were males, 69 (23.4\%) were females ( $M$ to $F$ ratio 3.3:1) Table 2. Out of 293, 156 (53\%) had Acute (CAH), 71 (24\%) were HBV Carriers, $54(18.3 \%)$ had Chronic(CLD) Hepatitis, Cirrhosis and HCC patients were $14(4.7 \%)$. Generally, genotype D (Figure 1) was the most prevalent genotype in all categories of HBV patients, Acute (69.2\%), Chronic (72.2\%), Carrier (74.7\%)). Cirrhosis/HCC (62.2\%) were HBV/D positive. Genotype A was the second prevalent with 28 (13\%) in acute cases, 12 (22.2\%) in chronics, 14 (19.7\%) in carriers and $5(37.7 .8 \%)$ in Cirrhosis/HCC patients. Mixed genotype A+D was found in 20 (12.8\%) of Acute patients, $3(5.6 \%)$ of Chronic and $4(5.6 \%)$ of carriers (Table 3).

\section{Discussion}

This is the first study from Pakistancomparing the clinical outcome of HBV-related liver disease in patients infected with different HBV genotypes using a PCR based method. Out of $295 \mathrm{HBsAg}$ positive registered patients, 225 (77\%) were males, and $69(23 \%)$ were females ( $M$ to $F$ ratio approximately 3.3:1) who were suffering from various liver conditions were genotyped (Table 2). Genotype A, D and both $\mathrm{A}$ and $\mathrm{D}$ (figure 1) were present in all categories of HBV patients but the most prevalent genotype was D in all conditions except cirrhosis in which genotype A was dominant. This pattern of genotype prevalence in Pakistan is in accordance with studies from South East Asia, especially countries sharing borders with Pakistan such as Afghanistan, Iran and India having dominance of genotype D. Chattopadhyay [21] reports, in a similar study from India that Genotypes D and A were present in all CLDB patient categories and genotype $\mathrm{D}$ was dominant. Generally, apart from HBV genotype B and C there is lack of information about the clinical course of HBV infected patients with other genotypes.

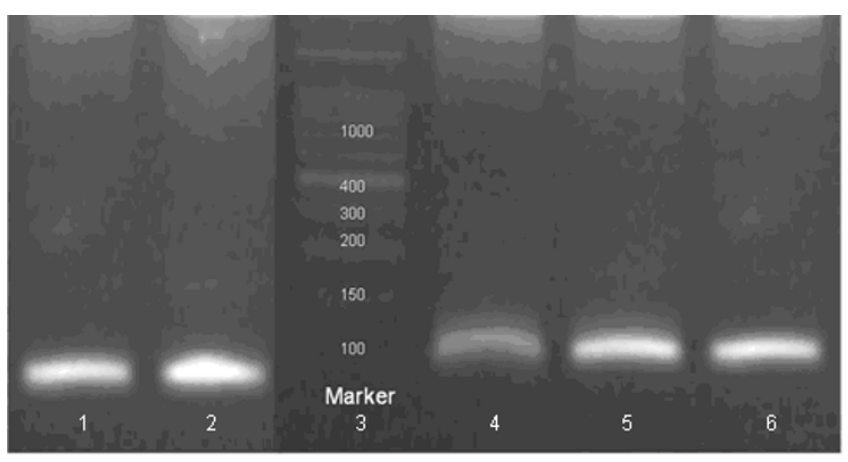

\section{Figure I}

$3 \%$ agarose gel showing genotype specific bands in patients infected with hepatitis B virus. Lane I and 2 show HBV genotype A specific 68 bp band; Lane 3 show 100 bp marker; Lane 4,5 and 6 show HBV genotype D specific I 19 bp band. 
Table I: Diagnosis according to gender in different categories of patients

\begin{tabular}{|c|c|c|c|c|c|c|}
\hline \multirow[t]{2}{*}{ Diagnosis } & \multicolumn{2}{|c|}{ Male $(n=226)(76.6 \%)$} & \multicolumn{2}{|c|}{ Female $(n=69)(23.4 \%)$} & \multicolumn{2}{|c|}{ Total $(n=295)$} \\
\hline & Number & Percent & Number & Percent & Number & Percent \\
\hline Acute $(\mathrm{CAH})$ & 124 & 54.86 & 32 & 46.3 & 156 & 52.7 \\
\hline Chronic (CLD) & 43 & 19.0 & 11 & 16.0 & 54 & 18.2 \\
\hline Carrier & 48 & 21.2 & 23 & 33.3 & 71 & 24 \\
\hline Cirrhosis/HCC & 11 & 4.8 & 3 & 4.3 & 14 & 4.7 \\
\hline
\end{tabular}

The clinical significance of different HBV genotypes has become increasingly recognized in patients with acute and chronic infection [22]. Genotyping of Acute patients in this study revealed genotype $\mathrm{D}(69.2 \%)$ as most prevalent genotype, whereas, $\mathrm{A}$ and $\mathrm{AD}$ were $18.0 \%$ and $12.8 \%$ respectively. There is paucity of information on the correlation between HBV genotypes and outcome of acute HBV infection. Acute HBV infection in Europe in earlier studies was found to be associated with genotype D $[23,24]$, but recently it has been demonstrated that $\mathrm{A}$ is the most prevalent amongst the patients with acute Hepatitis B [25]. Similarly a study from Japan demonstrates HBV genotype A in patients with acute hepatitis B where the most prevalent genotype Band C lead to chronic infection [26]. This leads us to believe that different genotypes may be associated with different rates of progression from acute to chronic HBV infection. If we conclude that these reports are possibly not reflecting the geographical difference but instead are showing the most prevalent genotype as most virulent as in the case of Europe then why is genotype A more common in Acute infection in Japanese patients when it should be B or C.

In Chronic infection levels of viremia are generally low. The strong determinant of chronicity is age at the time of infection. Long-term prognosis is poorer among HBeAgnegative individuals compared to their counterparts who are HBeAg-positive. In this study $18.4 \%$ had Chronic (CLD) Hepatitis. Out of 54 chronic patients, $72.2 \%$ had genotype $\mathrm{D}, 22.2 \%$ had $\mathrm{A}$ and $5.6 \%$ had $\mathrm{AD}$. This is in contrast to a study by Mayerat et al. [23] which suggested that the chronic infection by HBV could be more frequently associated with genotype A than genotype D. Whereas, genotype $\mathrm{D}$ was more prevalent among patients with resolving acute $\mathrm{HBV}$ infection, suggesting that HBV genotype $\mathrm{D}$ was associated with a lower rate of chronic HBV infection; however, Erhardt et al.'s [27] study on comparison of HBV genotypes A and D report that the rate of interferon-induced HBeAg seroconversion was lower among patients with genotype $\mathrm{D}$ than among those with genotype A ( $6 \%$ vs. $37 \%$ ), whereas, the influence of these genotypes on acute HBV infection was inconclusive. HBV genotype $\mathrm{D}$ has also been described as the genotype of intravenous illicit drug users [28].

During the Carrier state, low HBsAg levels are marked by HBeAg negativity with anti-HBe positivity, low HBV DNA level and repeatedly normal ALT. In this study the highest prevalence of Genotype D was found in HBV asymptomatic carriers $(74.7 \%)$. Borchani [29] also reports that

Table 2: Genotype distribution according to disease and gender

\begin{tabular}{|c|c|c|c|c|}
\hline \multicolumn{2}{|c|}{ Diagnosis/Genotype } & \multirow{2}{*}{$\begin{array}{c}\text { Male } n=226(76.6 \%) \\
124\end{array}$} & \multirow{2}{*}{$\begin{array}{c}\text { Female } n=69(23.4 \%) \\
32\end{array}$} & \multirow{2}{*}{$\begin{array}{c}\text { Total }(n=295) \\
156(52.9 \%)\end{array}$} \\
\hline Acute (CAH) & & & & \\
\hline Genotype & $\mathrm{D}$ & $88(71.0 \%)$ & $20(62.5 \%)$ & $108(69.2 \%)$ \\
\hline & A & $23(18.5 \%)$ & $5(15.6 \%)$ & $28(\mid 8.0 \%)$ \\
\hline & $A D$ & $13(10.5 \%)$ & 7 (21.9\%) & $20(12.8 \%)$ \\
\hline Chronic (CLD) & & 43 & II & $54(18.3 \%)$ \\
\hline \multirow[t]{3}{*}{ Genotype } & $\mathrm{D}$ & 30 (69.8\%) & $9(81.8 \%)$ & $39(72.2 \%)$ \\
\hline & $A$ & $10(23.3 \%)$ & $2(18.2 \%)$ & $12(22.2 \%)$ \\
\hline & $A D$ & $3(6.9 \%)$ & - & $3(5.6 \%)$ \\
\hline Carrier (asymptor & & 48 & 23 & $71(24 \%)$ \\
\hline \multirow[t]{3}{*}{ Genotype } & $\mathrm{D}$ & 38 (79.2\%) & 15 (65.2\%) & $53(74.7 \%)$ \\
\hline & A & $6(12.5 \%)$ & $8(34.8 \%)$ & $14(19.7 \%)$ \\
\hline & $A D$ & $4(8.3 \%)$ & - & $4(5.6 \%)$ \\
\hline Cirrhosis/HCC & & II & 3 & $14(4.7 \%)$ \\
\hline \multirow[t]{3}{*}{ Genotype } & $\mathrm{D}$ & 7 (63.6\%) & I(33.3\% & 8 (57.14\%) \\
\hline & A & $4(36.3 \%)$ & $2(66.6 \%)$ & $6(43.8 \%)$ \\
\hline & $A D$ & - & - & - \\
\hline
\end{tabular}


Table 3: Primer sequences used for HBV genotyping by nested PCR (position, specificity, and polarity). An "M " represents a nucleotide that could be either an $A$ or a $C ;$ a "Y" represents a nucleotide that could be either a $C$ or a T. nt, nucleotide.

\begin{tabular}{llll}
\hline & Primers & Sequence & Gene/CDS \\
\hline Step-one PCR & PIb universal, sense) & 5'-TCA CCA TAT TCT TGG GAA CAA GA-3' & nt2823-2845, \\
& SI-2 universal, antisense) & 5'-CGA ACC ACT GAA CAA ATG GC-3' & nt685-704, \\
Step-two PCR & B2 sense & 5'-GGC TCM AGT TCM GGA ACA GT-3' & nt67-86, types A specific, to E \\
Mix A & BAIR antisense & 5'-CTC GCG GAG ATT GAC GAG ATG T-3' & ntII3-I34, type A specific, \\
& BBIR antisense & 5'-CAG GTT GGT GAG TGA CTG GAG A-3' & nt324-345, type B specific, \\
& BCIR antisense) & 5'-GGT CCT AGG AAT CCT GAT GTT G-3' & nt I65-I86, type C specific, $\quad$ 28I bP \\
\hline
\end{tabular}

Genotype D as the most prevalent amongst theie Asymptomatic Carrier patients (67.2\%). A study in Italy has found that carriers of HBsAg who are symptom-free and whose liver function tests are normal have an excellent prognosis and the risk of hepatocellular carcinoma was low over the mean follow-up period of about 30 years [30]. The prognosis of the inactive carrier is generally good and well supported by long-term follow-up studies [31-33]. An estimated $20 \%$ to $30 \%$ of HBsAg carriers may develop reactivation of hepatitis $\mathrm{B}$ with elevation of biochemical levels, high serum DNA level with or without sero-reversion to $\mathrm{HBeAg}$. Recurrent episodes of reactivation or sustained reactivation can occur and contribute to progressive liver disease and decompensation especially, in the immunosuppressed individuals. Frequently, HBV reactivation is usually asymptomatic, but it may mimic acute viral hepatitis [34].

Cirrhosis and Hepatocellular Carcinoma (HCC) are two major long-term complications of chronic HBV infection which developed in 14 of our patients ( 11 males and 3 females). Five had developed cirrhosis and 9 hepatocellular carcinoma. Chronically infected subjects have a 100 times increased risk of hepatocellular carcinoma compared to non-carriers. HBsAg positivity increases risk of developing HCC by 10 folds and HBeAg positivity by 60 folds, whereas, a detectable HBV DNA level yields a 4 fold increased risk of HCC [35]. Regarding the genotype distribution in this study HBV genotype D was most prevalent among the HCC patients and genotype A in cirrhosis patients. Four out of five Cirrhosis patients in this study had HBV genotype A. A similar study from Spain [36] reports genotype $\mathrm{A}$ as more virulent because earlier the core antigen seroconversion rates were similar with genotypes A and D, but sustained biochemical and virological remission was not common with patients with genotype A who had HBeAg seroconversion. These patients had also higher rates of HBsAg clearance. These results indicate that HBV genotype A is associated with more marked ALT elevation, a higher rate of HBeAg positivity and presence of liver cirrhosis. [37]. Thus, it would be interesting to speculate that HBV genotype A could indeed be more prone to chronic infection than genotype D [38].
Among the nine patients in this study who developed HCC two were females and seven were males. Age ranged from 35 yrs to 68 yrs. Genotype D being most prevalent was present in $7(77.7 \%)$ patients, whereas genotype $\mathrm{A}$ in two patients, who developed HCC from chronic infection. Out of 5 with genotype $\mathrm{D}$, five males, age range 50 yrs to $68 \mathrm{yrs}$, were long time carriers (fifteen years after suffering from HBV infection) and the rest of the two, one male and other female were in the age range 35 yrs and 45 yrs. Thakur et al. [39] also concluded that genotype D may predict the occurrence of hepatocellular carcinoma in young Indian patients. Several studies have indicated that older age ( $>45$ years) is an important determinant of HCC. Having a first degree relative with HCC, the presence of cirrhosis, and reversion activity, all contribute to HCC development $[40,41]$. In this study, all patients with HCC were above 50 years of age but among the 5 patients who developed cirrhosis the age ranged from 22 years to 60 years. Kumar et al [37], also reports cirrhosis of liver to be more frequently in patients aged 25 years and above.

Generally, all categories of liver diseases showed male dominance, especially in HCC it is well documented. HCC incidence is three to six times higher in males than in females, suggesting a tumorigenic effect of androgens $[42,43]$. The 5 patients who developed cirrhosis from chronic condition were one female and 4 males again showing the predominance of male gender. In an experimentally induced carcinomas spontaneous neoplasms occurred at a higher rate in male rats and mice [44]. The studies on estradiol showed not only suppressive effect of estradiol on chemical hepatocarcinogenesis in rats [45] but also its cytoprotective effect against hepatocyte injury [46]. Thus it can be concluded that a better understanding of the biological mechanisms underlying the gender-associated differences observed in chronic HBV infection may provide valuable information on more effective treatment modalities in liver disease in both males and females [47].

Combination of $\mathrm{AD}$ exist where ever genotype $\mathrm{A}$ and $\mathrm{D}$ are prevalent such as India [39], Italy [48] etc. but none of studies report any virulence associated to it. In this study though $\mathrm{AD}$ combination was present in $12 \%$ of acute 
patients, $5.6 \%$ of chronic patients and 5.6\% of carriers, but none of the cirrhosis or HCC patients had combination of $\mathrm{AD}$.

Gerner et al. [49] observed that patients who were infected with HBV genotype A, after treatment with interferon and a relapse, had a switch of the genotype from HBV genotype A to D, whereas, Chen [50] observed that the dominant-genotype $\mathrm{C}$ changed to genotype $\mathrm{Ba}$ after anti-HBV e antigen (anti-HBe) seroconversion. Originally $\mathrm{HBV} / \mathrm{Ba}$ (B2) co-existed as a minor population with $\mathrm{HBV} / \mathrm{C}$ during the early course of acute HBV infection and then emerged and gradually became the dominant genotype. In our patients since the genotype was not checked before they developed severe conditions therefore, it can not be ascertained whether there was a switch of genotype. The mechanism for this recombination and switching remains enigmatic but this could be a possibility that long term sequelae could lead to reorganization of nucleotides. It is, hence, better advised that all HBV infected patients, regardless of status, should get screened after every 6 months with alpha-fetoprotein (AFP) and liver sonogram.

\section{Conclusion}

Genotyping of HBV may remain a research tool unless we prove that it can predict the risk of adverse outcomes (fulminant disease, cirrhosis, HCC) or can influence decisionmaking in managing these conditions. Studies so far around the world have lead us to believe that different genotypes may be associated with different rates of progression from acute to chronic HBV infection. However, differences in host and environmental factors make it difficult to extrapolate findings from one geographical region to another. Therefore, larger, in-depth longitudinal prospective studies are necessary, in various regions of the world, that could provide more information on the relationship of HBV genotypes to the severity of liver disease and thereby clinical outcome.

\section{Methods}

\section{Selection of subjects}

HBsAg positive 295 registered patients wereselected. irrespective of age and gender, with HBV-related liver disease such as Acute, Chronic, Cirrhosis, HCC, attending the outpatient Department of Pakistan Medical and Research Council(PMRC), Gastroenterology unit JPMC during the years 2006 to 2007, were selected for the study. All patients were HBV positive, registered patients Clinical data were retrieved from medical records, as were laboratory test results including hemogram, liver function tests, coagulation profile, and findings at abdominal ultrasonography, upper gastrointestinal endoscopy and liver biopsy. Liver cirrhosis and HCC were diagnosed either on the basis of histology, or on a combination of radiological, endoscopic and laboratory data. Serum samples were collected from the study patients when they came for the follow-up. A written as well as verbal informed consent was taken from each subject; however, in case of patients who were under the age of 18, parental consent was obtained. Prior to this approval of ZMUH ethical review committee was obtained. The following inclusion and exclusion criteria were applied while selecting patients for this study:

\section{Inclusion Criteria}

All healthy and diseased HbsAg positive individuals (healthy carriers, acute hepatitis, chronic hepatitis).

\section{Exclusion Criteria}

Patients with other hepatic viral markers (A, C, D, E) with HBV were excluded.

\section{DNA extraction}

DNA extraction from serum was done by DNA extraction kit (Promega Minipreps). The HBV genome was amplified by nested PCR using the universal primers (P1 and S1-2) for the outer primers, followed by two different mixtures containing type-specific inner primers as described above.

\section{PCR Amplification}

A modified version of nested PCR developed by Naito et al. [20] was followed. The sequences of PCR primers(supplied by Gene Link USA) used in this study were in the form of pairs step one and step-two designed on the basis of the conserved nature of nucleotide sequences in regions of the pre-S1 through $S$ genes, irrespective of theHBV genotypes (Figure 1). The HBV genome was amplified by sequence specific PCR using the universal primers (P1 and S1-2) for the outer primers, followed by two different mixtures containing type-specific inner primers as described in Table 1.

\section{Primer sequence and detail \\ Step one PCR}

The first PCR was carried out in a tube containing $50 \mu \mathrm{l}$ of a reaction buffer made up of the following components: $50 \mathrm{ng}$ each of the outer primer, a $200 \mu \mathrm{M}$ concentration of each of the four deoxynucleotides, $1 \mathrm{U}$ of Taq DNA polymerase (Perkin-Elmer, Norwalk, Conn.), and 1× PCR buffer containing $1.5 \mathrm{mM} \mathrm{MgCl}_{2}$. The extracted DNA was given an initial $10 \mathrm{~min}$ incubation at $95^{\circ} \mathrm{C}$ for a hot start reaction. After $10 \mathrm{~min}$ the PCR program was paused to dispense the master-mix in all tubes. The thermocycler (GeneAmp PCR system 2400,9600, and 9700A; PerkinElmer) was programmed to first incubate the samples for $10 \mathrm{~min}$ at $95^{\circ} \mathrm{C}$, followed by 35 cycles consisting of $94^{\circ} \mathrm{C}$ for min., $94^{\circ} \mathrm{C}$ for $20 \mathrm{~s}, 55^{\circ} \mathrm{C}$ for $20 \mathrm{~s}$, and $72^{\circ} \mathrm{C}$ for $1 \mathrm{~min}$. with a final extension of $5 \mathrm{~min}$. at $72^{\circ} \mathrm{C}$ and $4^{\circ} \mathrm{C}$. 


\section{Step two PCR}

Two second-round PCRs were performed for each sample, with the common universal sense primer (B2) and mix A for types $A$ through $C$ and the common universal antisense primer (B2R) and mix B for types D through F.A 2.5 $\mu$ aliquot of the first PCR product was added to two tubes containing the second sets of each of the inner primer pairs, each of the deoxynucleotides, AmpliTaq Gold DNA polymerase, and PCR buffer, as in the first reaction. These were amplified for35 cycles with the following parameters: preheating at $94^{\circ} \mathrm{C}$ for $3 \mathrm{~min}, 15$ cycles of amplification at $94^{\circ} \mathrm{C}$ for $20 \mathrm{~s}, 58^{\circ} \mathrm{C}$ for $30 \mathrm{~s}$, and $72^{\circ} \mathrm{C}$ for $40 \mathrm{~s}$, and an additional 20 cycles of $94^{\circ} \mathrm{C}$ for $30 \mathrm{~s}, 60^{\circ} \mathrm{C}$ for $30 \mathrm{~s}$, and $72^{\circ} \mathrm{C}$ for $45 \mathrm{~s}$ with an extension of $7 \mathrm{~min}$ at $72^{\circ} \mathrm{C}$ and incubation at $4^{\circ} \mathrm{C}$. Genotypes of $\mathrm{HBV}$ for each sample were determined by identifying the genotype-specific DNA bands. The two different second-round PCR products from one sample were separately electrophoresed on a 3\% agarose gel,(1\% agarose plus 2\% Nusieve Agarose) stained with ethidium bromide, and evaluated under UV light. The sizes of PCR products were estimated according to the migration pattern of a 50-bp DNA ladder (Pharmacia Biotech, Uppsala, Sweden).

\section{Competing interests}

The author(s) declare that they have no competing interests.

\section{Authors' contributions}

SB, AAS and WA designed the Research project. SB did all the bench work. SB and AAS wrote the manuscript. WA, HQ and AA clinically assessed the patients prior to selection and also helped in the clinical data retrieval from the medical records (all were their registered patients).

\section{Acknowledgements}

This study was supported by grant from Pakistan Medical Research Council (PMRC). The authors are thankful to Syed Ejaz Alam for assistance in statistical analysis.

\section{References}

I. Kao JH, Chen DS: Overview of hepatitis $\mathbf{B}$ and $\mathbf{C}$ viruses. In Infectious causes of cancer: targets for intervention Edited by: Goedert IJ. Humana Press Inc., Totowa, N.j; 2000:3 I3-330.

2. Zuckerman JN, Zuckerman AJ: Current topics in hepatitis B. J Infect 2000, 4 I(2): I30-136.

3. Lee WM: Hepatitis B infection. New England Journal of Medicine 1997, 337:1733-1745.

4. Bowyer SM, Sim GM: Relationship within and between the genotypes of Hepatitis B virus at point across the genome: footprints of recombination in certain isolates. Journal of General Virology 2000, 81:379-392.

5. Sherlock S, Dooley J: Virus hepatitis. Diseases of the liver and biliary system. I0th edition. London: Blackwell Science; 1997:265-302

6. Bläckberg J, Kidd-Ljunggren K: Occult hepatitis B virus after acute self-limited infection persisting for $\mathbf{3 0}$ years without sequence variation. Journal of Hepatology 2000, 33:992-997.

7. Seeff LB, Beebe GW, Hoofnagle JH, Norman JE, Buskell-Bales Z, Waggoner JG, Kaplowitz N, Koff RS, Petrini JL Jr, Schiff ER: A serologic follow-up of the 1942 epidemic of post-vaccination hepatitis in the United States Army. N Engl J Med 1987, 3 I 6:965-970.

8. Lok AS, McMahon BJ: Chronic hepatitis B. Hepatology 200I, 34: |225-|24|.

9. Sugauchi F, Chutaputti A, Orito E, Kato $H$, Suzuki S, Ueda $R$, Mizokami M: Hepatitis B virus genotypes and clinical manifestation among hepatitis B carriers in Thailand. J Gastroenterol Hepatol 2002, I 7:67I-676.

10. Orito E, Ichida T, Sakugawa H, Sata M, Horiike N, Hino K, Okita K, Okanoue T, lino S, Tanaka E, Suzuki K, Watanabe H, Hige S, Mizokami $M$ : Geographic distribution of hepatitis B virus (HBV) genotype in patients with chronic HBV infection in Japan. Hepatology 200I, 34:590-594.

II. Ishikawa K, Koyama T, Masuda T: Prevalence of HBV genotypes in asymptomatic carrier residents and their clinical characteristics during long-term follow-up: the relevance to changes in the HBeAg/anti-HBe system. Hepatol Res 2002, 24:I.

12. Westland C, Delaney W, Yang H, Gibbs C, Miller M, Wulfsohn MJ: Hepatitis $B$ virus genotypes and virologic response in 694 patients in phase III studies of adefovir dipivoxil I. Gastroenterology 2003, 125:107-116.

13. Orito E, Mizokami M, Sakugawa H, Michitaka K, Ishikawa K, Ichida T, Okanoue T, Yotsuyanagi $\mathrm{H}$, lino S: A case-control study for clinical and molecular biological differences between hepatitis B viruses of genotypes B and C. Japan HBV Genotype Research Group. Hepatology 200I, 33:218-223.

14. Sumi H, Yokosuka O, Seki N, Arai M, Imazeki F, Kurihara T, Kanda T, Fukai $\mathrm{K}$, Kato $M$, Saisho $\mathrm{H}$ : Influence of hepatitis B virus genotypes on the progression of chronic type $B$ liver disease. Hepatology 2003, 37:19-26.

15. Khichi GQK, Channar MS: Prevalence of hepatitis B carriers among children in Bahawalpur urban slums. Pakistan Journal of Medical Sciences 2000, I6(4):238-24I.

16. Khattak MF, Salamat N, Bhatti FA, Qureshi TZ: Seroprevalence of hepatitis B, C and HIV in blood donors in northern Pakistan. J Pak Med Assoc 2002, 52(9):398-402.

17. Akhtar S, Younus M, Adil S, Hassan F, Jafri SH: Epidemiologic study of chronic hepatitis $B$ virus infection in male volunteer blood donors in Karachi, Pakistan. BMC Gastroenterol 2005, 5:26.

18. Abbas Z, Muzaffar R, Siddiqui A, Naqvi SAA, Rizvi SAH: Genetic variability in the precore and core promoter regions of hepatitis B virus strains in Karachi. BMC Gastroenterology 2006, 6:20.

19. Alam MM, Zaidi SZ, Shaukat S, Sharif S, Angez M, Naeem A, Saleha S, Butt JA, Malik SA: Common Genotypes of Hepatitis B virus prevalent in Injecting drug abusers (addicts) of North West Frontier Province of Pakistan. Virology Journal 2007, 4:63.

20. Naito H, Hayashi S, Abe K: Rapid and specific genotyping system for hepatitis B virus corresponding to six major genotypes by PCR using type-specific primers. I Clin Microbiol 200I, 39(I):362-364.

21. Chattopadhyay S, Das BC, Kar P: Hepatitis B virus genotypes in chronic liver disease patients from New Delhi, India. World Gastroenterol 2006, I 2:6702-6706.

22. Kar P: Hepatitis B virus genotyping: will it stand the test of time? Indian / Gastroenterol 2005, 24(I):4-5.

23. Mayerat C, Mantegani A, Frei PC: Does hepatitis B virus (HBV) genotype influence the clinical outcome of HBV infection? Viral Hepat 1999, 6:299-304.

24. Leblebicioglu H, Eroglu C: Acute hepatitis B virus infection in Turkey: epidemiology and genotype distribution. Clin Microbiol Infect 2004, 10:537-54l.

25. Lyra AC, Pinho JR, Mello IM, de M Malta F, Gomes MM, Di Bisceglie AM, Lyra LG, Carrilho FJ, da Silva LC: Distribution of hepatitis B virus (HBV) genotypes among patients with acute viral hepatitis. J Clin Gastroenterol 2005, 39:8I-2.

26. Suzuki $Y$, Kobayashi M, Ikeda K, Suzuki F, Arfase $Y$, Akuta N, Hosaka T, Saitoh S, Kobayashi M, Someya T, Matsuda M, Sato J, Watabiki S, Miyakawa $Y$, Kumada $\mathrm{H}$ : Persistence of acute infection with hepatitis $\mathbf{B}$ virus genotype $\mathbf{A}$ and treatment in Japan. I Med Virol 2005, 76:33-9.

27. Erhardt A, Reineke U, Blondin D, Gerlich WH, Adams O, Heintges T, Niederau C, Haussinger D: Mutations of the core promoter and response to interferon treatment in chronic replicative hepatitis B. Hepatology 2000, 3 I:716-725. 
28. Van Ameijden EJ, Van den Hoek JA, Mientjes GH, Coutinho RA: A longitudinal study on the incidence and transmission patterns of HIV, HBV and HCV infection among drug users in Amsterdam. Eur J Epidemiol 1993, 9:255-62.

29. Borchani-Chabchoub I, Gargouri A, Mokdad-Gargouri R: Genotyping of Tunisian hepatitis $B$ virus isolates based on the sequencing of preS2 and S regions. Microbes Infect 2000, 2(6):607-612.

30. Manno M, Cammà C, Schepis F, Bassi F, Gelmini R, Giannini F, Miselli F, Grottola A, Ferretti I, Vecchi C, De Palma M, Villa E: Natural history of chronic HBV carriers in northern Italy: morbidity and mortality after 30 years. Gastroenterology 2004, I 27(3):756-763.

31. Hsu YS, Chien RN, Yeh CT, Sheen IS, Chiou HY, Chu CM, Liaw YF Long-term outcome after spontaneous $\mathrm{HBeAg}$ seroconversion in patients with chronic hepatitis B. Hepatology 2002 35: I522-1527.

32. de Franchis R, Meucci G, Vecchi M, Tatarella M, Colombo M, Del Ninno E, Rumi MG, Donato MF, Ronchi G: The Natural history of symptomatic hepatitis B surface antigen carriers. Ann Intern Med 1993, I I 8:191-194.

33. Bellentani S, Dal Molin G, Miglioli L, Crocè L, Masutti F, Castiglione A, Campello C, Tiribelli C: Natural history of HBV infection: a 9 years follow-up of the Dionysos cohort. J Hepatol 2002 36:228.

34. Pan Calvin Q, Jin X: Zhang2Natural History and Clinical Consequences of Hepatitis B Virus Infection. International Journal of Medical Sciences 2005, 2:36-40.

35. Yang $\mathrm{HI}$, Lu SN, et al.: Hepatitis $\mathbf{B}$ e antigen and the risk of hepatocellular carcinoma. N Engl J Med 2002, 347:168-174.

36. Sanchez-Tapias JM, Costa J, Mas A, Brugera M, Rodes J: Influence of hepatitis $B$ virus genotype on the long-term outcome of chronic hepatitis B in Western patients. Gastroenterology 2002 123: 1848-1856

37. Kumar SI, Pandey R, Naik S, Aggarwal R: Hepatitis B virus genotype $A$ is more often associated with severe liver disease in northern India than is genotype D. Indian J Gastroenterol 2005, 24:19-22.

38. Ribeiro NRC, Campos GS, Angelo ALD, Braga EL, Santana N, Gomes MMS, Pinho JRR, De Carvalho WA, Lyra LGC, Lyra AC: Distribution of Hepatitis B Virus Genotypes Among Patients With Chronic Infection. Liver International 2006, 26:636-642.

39. Thakur V, Guptan RC, Kazim SN, Malhotra V, Sarin SK: Profile, spectrum and significance of HBV genotypes in chronic liver disease patients in the Indian subcontinent. J Gastroenterol Hepatol 2002, 17:165-170.

40. Benvegnu L, Fattovich G, Noventa F, Tremolada F, Chemello L, Cecchetto A, Alberti A: Concurrent hepatitis B and $C$ virus infection and risk of hepatocellular carcinoma in cirrhosis. Cancer 1994, 74:2442-2448.

4I. Tsai JF, Jeng JE, Ho MS, Chang WY, Hsieh MY, Lin ZY, Tsai JH: Effect of hepatitis $C$ and $B$ virus infection on risk of hepatocellular carcinoma: a prospective study. Br J Cancer 1997, 76:968-974.

42. McMahon BJ, Alberts SR, Wainwright RB, Bulkow L, Lanier AP: Hepatitis B-related sequelae. Prospective study in 1400 hepatitis B surface antigen-positive Alaska Native carriers. Arch Intern Med 1990, 150:105I-1054.

43. Beasley RP: Hepatitis B virus. The major etiology of hepatocellular carcinoma. Cancer 1988, 61:1942-1956.

44. Tanaka Y, Mukaide M, Orito E, Yuen MF, Ito K, Kurbanov F, Sugauch F, Asahina Y, Izumi N, Kato M, Lai CL, Ueda R, Mizokami M: Specific mutations in enhancer II/core promoterof hepatitis $B$ virus subgenotypes $\mathrm{Cl} / \mathrm{C2}$ increase the risk of hepatocellular carcinoma. J Hepatol 2006, 45:646-653.

45. Shimizu I, Yasuda M, Mizobuchi Y, Ma YR, Liu F, Shiba M, Horie T, Ito S: Suppressive effect of oestradiol on chemical hepatocarcinogenesis in rats. Gut 1998, 42: II $12-119$

46. Itagaki T, Shimizu I, Cheng X, Yuan Y, Oshio A, Tamaki K, Fukuno H, Honda $\mathrm{H}$, Okamura $\mathrm{Y}$, Ito $\mathrm{S}$ : Opposing effects of oestradiol and progesterone on intracellular pathways and activation processes in the oxidative stress induced activation of cultured rat hepatic stellate cells. Gut 2005, 54:1782-1789.

47. Ichiro Shimizu, Nao Kohno, Katsuyoshi Tamaki, Masayuki Shono, HuiWei Huang, liang-Hong He, Deng-Fu Yao Female hepatology: Favorable role of estrogen in chronic liver disease with hepatitis B virus infection. World J Gastroenterol 13(32):4295-4305. 2007 August 28
48. Morozov V, Pisareva M, Groudinin M: Homologous recombination between different genotypes of hepatitis B virus. Gene 2000, 260:55-65.

49. Gerner PR, Friedt M, Oettinger R, Lausch E, Wirth S: The hepatitis $B$ virus seroconversion to anti-HBe is frequently associated with HBV genotype changes and selection of preS2-defective particles in chronically infected children. Virology 1998, 245: 163-172

50. Chen BF, Liu CJ, Jow GM, Chen PJ, Kao JH, Chen DS: Evolution of Hepatitis B virus in an acute hepatitis B patient co-infected with genotypes B and C. J Gen Virol 2006, 87:39-49.
Publish with Bio Med Central and every scientist can read your work free of charge

"BioMed Central will be the most significant development for disseminating the results of biomedical research in our lifetime. "

Sir Paul Nurse, Cancer Research UK

Your research papers will be:

- available free of charge to the entire biomedical community

- peer reviewed and published immediately upon acceptance

- cited in PubMed and archived on PubMed Central

- yours - you keep the copyright
BioMedcentral 